\title{
NUMERICAL AND EXPERIMENTAL IDENTIFICATION OF CRACK IN THE STACKER CONSTRUCTION
}

\author{
Jerzy CZMOCHOWSKI ${ }^{1}$, Pawel MAŚLAK ${ }^{1}$, Grzegorz PRZYBYLEK ${ }^{1}$, \\ Mariusz STAŃCO $^{1}$, Damian PIETRUSIAK ${ }^{1}$
}

1 Wroclaw University of Science and Technology, Faculty of Mechanical Engineering, Department of Machine Design and Research, Lukasiewicza 7/9, 50-371 Wroclaw. Poland. email: jerzy.czmochowski@pwr.edu.pl,grzegorz.przybyłek@pwr.edu.pl,pawel.maslak@pwr.edu.pl, mariusz.stanco@pwr.edu.pl,damian.pietrusiak@pwr.edu.pl

\section{Introduction}

In lignite mines, mining and quarrying machines are used for the extraction of coal and overburden. The set of machines is used to remove the overburden: excavator - belt conveyor - stacker [1]. Due to the long life of these machines (often above 30 years) there is a problem to assess their continued safe use. Excavators and stackers are especially heavy loads. In today's mines the overburden is characterized by hard rock layers, resulting in faster degradation of the load-bearing structures of these machines. The publications describe the failures of these machines, the main caused by fatigue cracks [2]. Also in the bearer carrier systems due to their large size, large extensibility, there are significant inertia forces especially in transient states, such as start-up of ride or start-up of rotate of the bodywork.

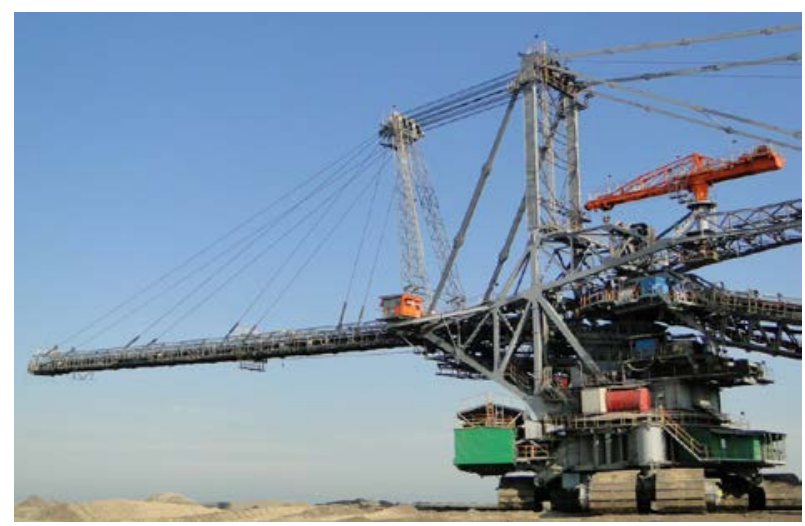

Fig. 1. Stacker A2RsB 15400

Using the method presented in the paper [3], one of the largest stacker shown on Fig. 1 was carried out in Poland in the lignite mine Bełchatów. FEM numerical method was used to identify the places with the highest stress due to fatigue strength and non-destructive experimental methods.

\section{Numerical analysis}

One of the basic tasks in determining the condition of machines after long-term use is to determine the places of high stress [3, 4]. For this purpose, the finite element method was used. The numerical model of the stacker carrier structure is shown in Fig. 2.

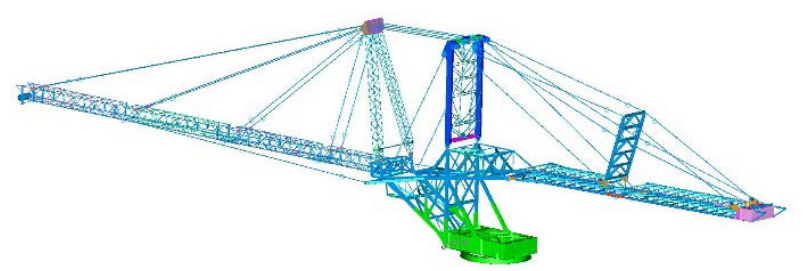

Fig. 2. The numerical model of the stacker

The numerical model uses discretization using beam and shell finite elements. The bar structures of the discharge boom, the counterweight boom and the masts were modeled using beam finite elements, the support structure, the tower were modeled with shell elements. Numeric calculations were performed for load cases defined in DIN 22261 [5]. Particularly important in these calculations are the cases to determine the fatigue strength used in the proof of service life. The results from these calculations show the places susceptible to fatigue cracks. Figure 3 shows stress of the structure with a high level of stress difference, in which serious fracture has been identified. This is a particularly important place, as all machine assemblies are connected to this carrier system. The failure of one of the beams of this carrying system could have resulted in a catastrophe of the whole machine. 


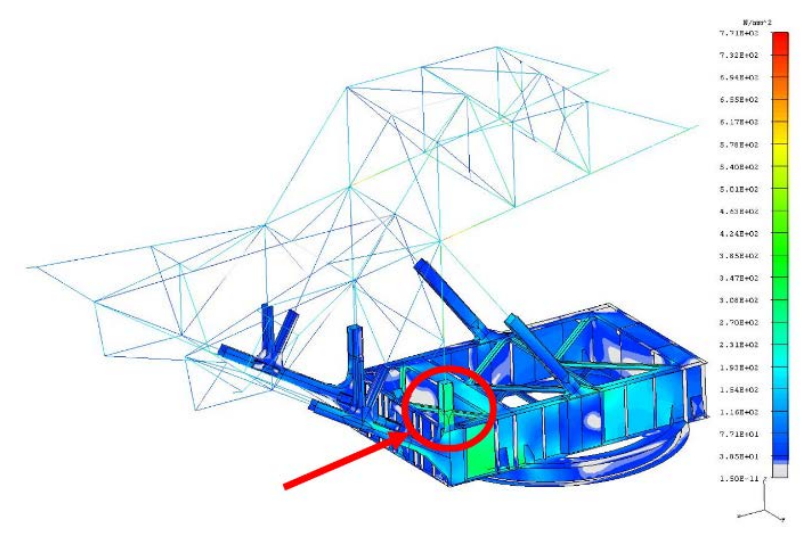

Fig. 3. Stress for load case H1b [5] with marked place of crack

\section{Experimental investigations}

Detailed inspection, vibration measurement at work [6, 7], deformation measurements, corrosion defects measurements and non-destructive defectoscopy (NDT) tests at welded joints are carried out in the assessment of the condition of machines after many years of operation. Weld joints due to the notch effect and changes in the material structure are susceptible to fatigue cracks. In the investigated stacker, special attention was paid to the examination of welds in places of high fatigue stress. A fatigue crack was detected at the location of one of the joint in its central section (Figure 4.). Magnetic-powder method [8] was used to detect cracking.

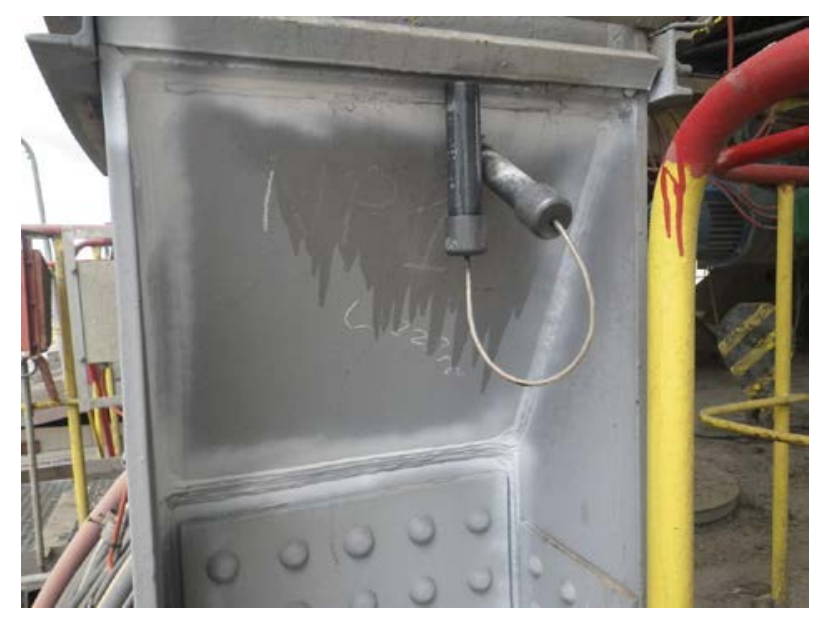

Fig. 4. Cracking at the weld in the tower supporting structure

A crack of about $20 \mathrm{~cm}$ in length was found at the weld at the change of box cross section to Ibeam. Upon detection of this cracks, the machine has been stopped to repair the damage.

\section{Remarks}

- The finite element method was used to determine the places of high fatigue life in the structure of the stacker

- For the identification of cracks, a nondestructive (NDT) method was used in welded joints.

\section{References}

[1] Kasztelewicz Z., Koparki wielonaczyniowe i zwałowarki taśmowe. Technologia pracy. Fundacja Nauka i Tradycje Górnicze Wydział Górnictwa i Geoinżynierii AGH, Kraków 2012

[2] Rusiński E., Czmochowski J., Iluk A., Kowalczyk M., An analysis of the causes of a BWE counterweight boom support fracture. Engineering Failure Analysis 2010, 17, 17991

[3] Rusiński E., Czmochowski J., Moczko P., Pietrusiak D., Surface Mining Machines. Problems of Maintenance and Modernization. Springer, 2017

[4] Czmochowski J., Przybyłek G., Działak P., Maślak P., Stańco M., Method of Technical Check of Superstructure of Bucket-Chain Excavator. Materials Today: Proceedings, 2017

[5] DIN 22261-2:2006 - Bagger Absetzer und Zusatzgeräte in Braunkohlentagebauen

[6] Czmochowski J.: Identyfikacja modeli modalnych maszyn urabiających w górnictwie węgla brunatnego, Oficyna Wydawnicza Politechniki Wrocławskiej, Wrocław 2008

[7] Lalanne C. Mechanical Vibration and Shock Analysis, Fatigue Damage, Wiley, 2009

[8] Lewińska-Romicka A.: Badania nieniszczące. Podstawy defektoskopii. Wydawnictwo Naukowo-Techniczne. Warszawa 2001 